\title{
青森県高瀬川河口域の浅瀬が塩水遡上に与える影響に関する 三次元数值流動解析による研究
}

\author{
A Numerical Investigation on an Influence of a Shallow Water Area \\ on the Salt Water Intrusion in River Takase
}

\author{
中村恭志 ${ }^{1} \cdot$ 石川忠晴 $^{2}$
}

\author{
Takashi NAKAMURA and Tadaharu ISHIKAWA
}

\begin{abstract}
The Takase River, a mild slope and short river from a brackish water lake named Lake Ogawara, has a wide shallow area expanding from the river mouth to the middle reach of channel. Previous studies suggest saline water intrusion to the lake is probably influenced by the existence of the shallow area. In this study, a three-dimensional numerical simulation was conducted for a whole reach of channel in order to investigate the flow characteristics in the shallow water area and its influence upon the vertical flow structure in the low-water channel. The numerical results showed that the flow retardation in the shallow water area is caused due to a replacement of fresh water bulk stored in that area, and the retardation intensifies the density stratification in the low-water channel.
\end{abstract}

\section{1.はじめに}

青森県東部に位置する高瀬川は，小川原湖と太平洋を 結ぶ延長 $6.6 \mathrm{~km}$ の感潮河川である（図-1). 図-2に示よう に，中上流部では高水敷が殆ど見られないが，河口から 中流部の河道幅が広がっている区間では，澪筋が狭小な 一方, 河道内の大部分は水深が極めて浅い浅瀬となるな ど，特異的な河道地形を持っている。潮汐変動に伴い太 平洋から塩水が時折遡上し, 高潮時には一部が小川原湖 に流入する。その結果，小川原湖では年間を通じて湖深 部に高塩分水層が存在し，この塩水遡上現象とそれに伴 う湖内での塩分循環は, 同湖の水質や生物に大きな特色 を与えている（西田ら，1999；鶴田ら，2002）。

河口から $5.5 \mathrm{~km}$ にある高瀬川観測所（以降高瀬橋地点） での塩分等のモニタリング観測から，塩水の遡上規模が 中程度の場合は緩混合，大規模の場合はほぼ強混合で湖 口付近の上流部に塩水が到達し, 強混合状態は日潮不等 の高高潮時に起こり易いなど，上流部での特徴的な混合 形態の変化が観測されている（石川ら，1991；長尾ら, 1996 ; 西田ら，1999；鶴田ら，2001）。このような混合 形態の変化の発生機構として, 高瀬川の特異的な地形形 状に着目した研究が行われている（藤原ら，1995，1997， 2000 ；成田ら，2003）。成田ら（2003）は, 河口付近の 浅瀬に多数の水温・塩分計を設置した集中観測を行い, 浅瀬に貯留されている淡水が澪筋表層へ遅れて排出され ることが，中規模遡上の場合に上流で緩混合となる原因

\footnotetext{
1 正会員 理博 東京工業大学准教授 大学院総合理工学 研究科環境理工学創造専攻

2 フェロー 工博

東京工業大学教授 大学院総合理工学 研究科環境理工学創造専攻
}

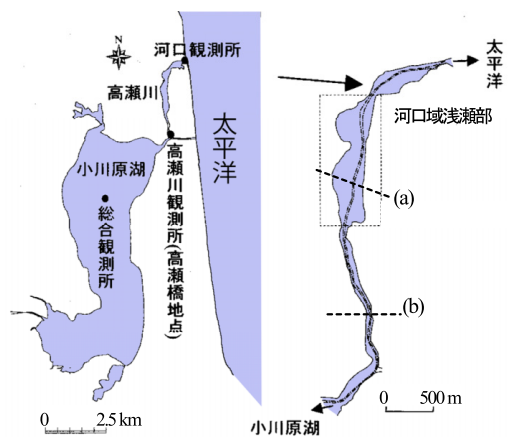

図-1＼cjkstart高瀬川の位置と形状
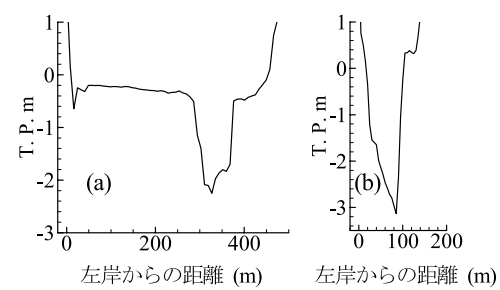

図-2 横断河床高分布.（a)浅瀬部と (b) 上流域について代表的 な形状を示す。（a）及び(b)の位置は図-1中に示した。

であると推察している. しかし，大規模遡上で強混合と なることに関しては, その発生機構の検証を行った研究 は見られない。そこで本研究では，浅瀬を含む河口から 小川原湖までの高瀬川全区間について詳細な地形形状を 用いた塩水密度流の三次元数值解析を行い, 浅瀬での塩 水挙動とそれによる縦断的な塩分分布への影響を塩水遡 上の規模が異なる場合について調べ，既往研究で示唆さ れている上流域での混合形態の変化の発生機構について 妥当性を確認することとした. 


\section{2. 数値流動モデルの検証}

\section{（1）数値モデルの概要}

数值モデルには三次元 CIP-Soroban 塩水流動モデルを 使用した（中村ら，2010）。基礎方程式は以下に示す三 次元非圧縮・非静水圧 $k-\varepsilon$ 乱流方程式である.

$$
\begin{aligned}
& \frac{D \mathbf{u}}{D t}=-\frac{\nabla p}{\rho}+\frac{\partial}{\partial x} v_{H} \frac{\partial \mathbf{u}}{\partial x}+\frac{\partial}{\partial y} v_{H} \frac{\partial \mathbf{u}}{\partial y}+\frac{\partial}{\partial z} v_{\text {eff }} \frac{\partial \mathbf{u}}{\partial z}+\mathbf{F} \\
& \frac{D k}{D t}=P_{k}+G_{k}-\varepsilon+\frac{\partial}{\partial x} \frac{v_{H}}{\sigma_{k}} \frac{\partial k}{\partial x}+\frac{\partial}{\partial y} \frac{v_{H}}{\sigma_{k}} \frac{\partial k}{\partial y}+\frac{\partial}{\partial z} \frac{v_{e f f}}{\sigma_{k}} \frac{\partial k}{\partial z} \ldots . \\
& \frac{D \varepsilon}{D t}=\left(C_{1} P_{k}-C_{2} \varepsilon\right) \frac{\varepsilon}{k}+\frac{\partial}{\partial x} \frac{v_{H}}{\sigma_{\varepsilon}} \frac{\partial \varepsilon}{\partial x}+\frac{\partial}{\partial y} \frac{v_{H}}{\sigma_{\varepsilon}} \frac{\partial \varepsilon}{\partial y}+\frac{\partial}{\partial z} \frac{v_{e f f}}{\sigma_{\varepsilon}} \frac{\partial \varepsilon}{\partial z} \\
& \frac{D S}{D t}=\frac{\partial}{\partial x} \frac{v_{H}}{\sigma_{T}} \frac{\partial S}{\partial x}+\frac{\partial}{\partial y} \frac{v_{H}}{\sigma_{T}} \frac{\partial S}{\partial y}+\frac{\partial}{\partial z} \frac{v_{e f f}}{\sigma_{T}} \frac{\partial S}{\partial z}
\end{aligned}
$$$$
\nabla \cdot \mathbf{u}=0
$$

$$
\begin{gathered}
P_{k}=v_{e f f}\left\{(\partial u / \partial z)^{2}+(\partial v / \partial z)^{2}\right\}, \quad G_{k}=\left(g v_{e f f} / \rho \sigma_{t}\right)(\partial \rho / \partial z) \\
v_{e f f}=v_{m o l}+v_{t u r b}=v_{m o l}+C_{\mu}\left(k^{2} / \varepsilon\right), \quad v_{H}=0.01 \times D^{4 / 3}
\end{gathered}
$$

ここで， $x, y$ と $z$ はそれぞれ河道縦断，横断及び鉛直方向 座標, $\mathbf{u}=(u, v, w)$ は流速, $\mathbf{F}=\left(u v / R, u^{2} / R,-g\right)$ は重力と 河道屈曲に伴う遠心力 ( $R$ は河道曲率半径),$k$ と $\varepsilon$ は乱 流エネルギーと散逸率， $v_{\text {mol }}$ と $v_{\text {turb }}$ は分子粘性と乱流粘性 係数, $p$ は圧力, $S$ は塩分, $\rho$ は密度である. 水平方向の 粘性係数 $v_{H}$ は水平方向の代表格子幅 $D$ からリチャードソ ンの $4 / 3$ 乗則を用いて求め, 係数 $C_{1}, C_{2}, C_{\mu}$ は k- $\varepsilon$ モデル の標準值を使用した (中村ら，2010). 以上に加え, 水 位 $h(t, x, y)$ の時間発展を次式に従い計算する.

$\partial h / \partial t+\partial m / \partial x+\partial n / \partial y=0$

$$
m(t, x, y)=\int_{b}^{h} u d z, \quad n(t, x, y)=\int_{b}^{h} v d z
$$

ここで $b(x, y)$ は河床高である．離散化には高精度補間 法のCIP 法と動的適合格子のSoroban格子を使用する. Soroban格子では，計算格子点の鉛直位置は各時間ステ ップで動的に調整され, 塩分躍層付近に集中配置するこ とで計算精度を向上させる。このモデルは，過去に利根 川などで塩水流動を精度良く再現した実績があるが（許 ら，2012），広く極めて浅く冠水している高水敷を持つ 河川へは適用されていない。そこでまず，成田ら（2003） により浅瀬の集中観測が行われた期間について再現計算 を行い，観測結果との比較から数值モデルの再現性を検 証した。

\section{（2）検証に用いた観測データの概要}

成田ら（2003）による集中観測は2002年8月3日から 8 月 10 日の期間に行われた。図-1に示す高瀬川観測所では 常時塩分と流速を計測しており, 小川原湖総合観測所と 河口観測所では水位が計測されている．期間中の水理諸量 を図-3に示す．集中観測では，図-4に示す浅瀬の下流側

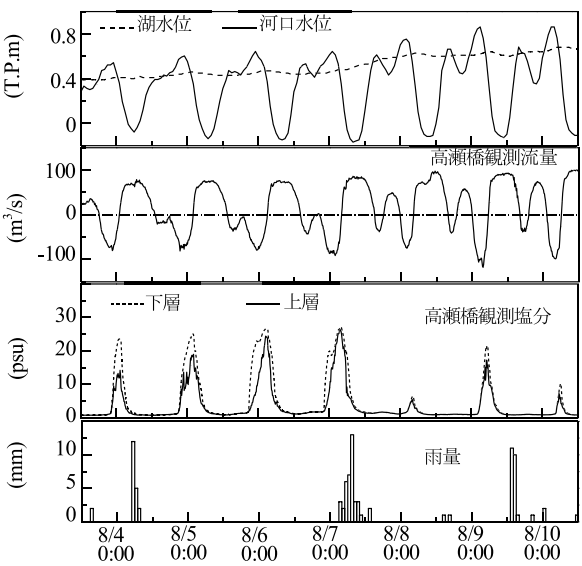

図-3 観測対象期間（2002年夏期）における湖水位，河口水 位，高瀬橋流量，高瀬橋塩分，雨量.

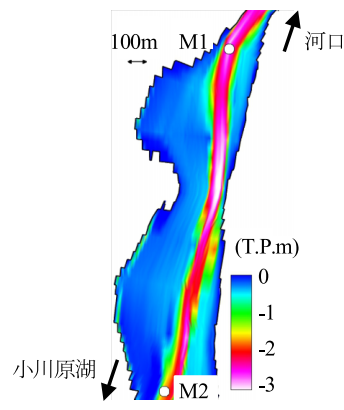

図-4＼cjkstart観測対象の河口域浅瀬部の河床標高と観測点位置。

（M1 地点）と上流側（M2 地点）の澪筋上に, 塩分水温計 をそれぞれ河床から $10 \mathrm{~cm}$ と $190 \mathrm{~cm}, 10 \mathrm{~cm}$ と $150 \mathrm{~cm}$ の位 置に設置して上下層での時系列塩分データが観測されてい る. 浅瀬には水温計と塩分水温計を設置し, 塩分水温計に おける塩分と水温の相関を基に水温計のデー夕を塩分に変 換し，面的な塩分分布の変化が測定されている.

\section{(3) 計算条件}

再現計算の期間は2002年 8 月 3 日 12:00から 8 月 10 日 12:00までとし，以下のような条件で計算を行った。

\section{a) 計算領域}

計算領域は河口から小川原湖総合観測所までの約 11 $\mathrm{km}$ とした。 国土交通省東北地方整備局高瀬川河川事務所 により2009年に実施された，200 m毎の横断河床高測量 結果を空間補間して計算に用いる河床地形とした。格子 間隔は，河道縦断方向に $\Delta x=40 \mathrm{~m}$ とし，横断方向は浅瀬 付近で $\Delta y=5 \mathrm{~m}$ ，それ以外は $10 \mathrm{~m}$ とした．鉛直方向の格 子間隔 $\Delta z$ は各時間ステップで調整され不均一となるが, 平均して $\Delta z=10 \mathrm{~cm}$ となるように格子点数を設定した.

\section{b）境界条件}

上流端では小川原湖総合観測所の実測水位を，下流端 では河口観測所の実測水位を毎時間データから与えた. 


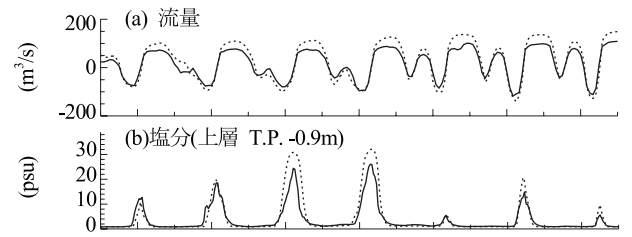

㺃

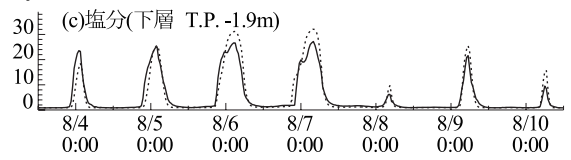

図-5 高瀬橋地点での（a）流量，（b）上層塩分，及び（c）下 層塩分の時系列．点線：再現計算，実線：観測結果。

塩分は上流端では小川原湖表層での対象期間中の平均塩 分（0.9 psu）を断面一様に与え，下流端では海水の塩分 （34 psu）を与えた。初期条件は静止状態とし，塩分は全 域で小川原湖表層平均塩分とし，水位は上下流端での観 測水位を縦断方向に線形補間することで与えた。また， 河床面上での摩擦応力 $\tau_{b}$ は河床上流速 $\mathbf{u}_{b}$ を用いて $\tau_{b}=$ $-\rho f_{b}\left|\mathbf{u}_{b}\right| \mathbf{u}_{b}$ で与えた，摩擦係数 $f_{b}$ は底質・植生等により変 化するが，これらの詳細な状況は不明なことから，河川 流動解析で推奨されている $f_{b}=0.0026$ を使用した $(\mathrm{Zi}$, 2008).

\section{（4）計算結果と観測データの比較}

高瀬橋地点に扔ける流量及び塩分の比較を図-5に示 す。なお，観測流量はADCPによる流速観測值から西田 ら（1999）の方法で換算したものである．図-5(a) に示 す様に，潮位変動に伴う全体的な流況はほぼ再現できて いる。一方，流量は順流・逆流時とも計算結果はやや過 大である．原因の一つとして摩擦係数 $f_{b}$ が過小であった ことが考えられる。流速鉛直偏差が小さい場合， $f_{b}$ とマ ニングの粗度係数 $n$ との間には $n^{2} \sim f_{b} H^{4 / 3} g^{-1}$ の関倸が成り 立つ. 水深 $H$ を澪筋での代表的水深 $(2 \mathrm{~m})$ とすれば，平 野の小流路に対する $n$ の概略值とされる $0.025 \sim 0.06$ （土 木学会，1999）は $f_{b}=0.0025 \sim 0.014$ に相当する. 使用し た $f_{b}=0.0026$ は下限值に近い值であり，上記範囲内でより 大きな值に調整する余地があると言える。また，図-5 (b) と（c）に示す様に，小規模の塩水遡上の場合に上層塩 分は下層塩分より低く, 大規模になると上層塩分も下層 塩分と同程度になるなど，遡上規模による上下層での差 異をよく再現している。その一方，8月6日と7日の大規 模遡上では，塩分の最大值はやや過大に計算されている. これらのイベントでは図-5（a）に示す様に逆流時流量が 過大に計算されて扔り，その結果最大塩分が過大となっ たと考えている。

次に, 浅瀬での塩水挙動の観測結果との比較を示す. 遡上規模が比較的大きかった8月6日から7日にかけての 一潮汐について，M1 と M2 地点の塩分時系列を図-6に, 河床面 $10 \mathrm{~cm}$ 上方での塩分平面分布を図-7に示す，遡上

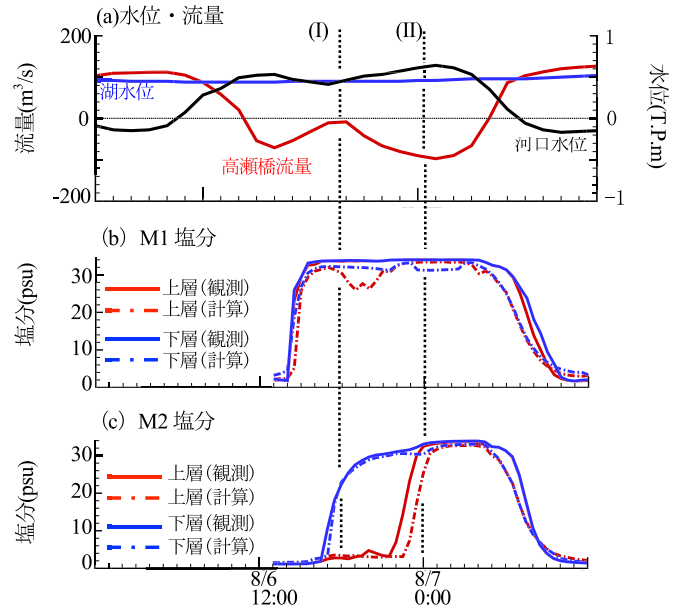

図-6 観測水位と高瀬橋流量（観測值），及びM1, M2 地点にお ける上下層塩分濃度の時系列。

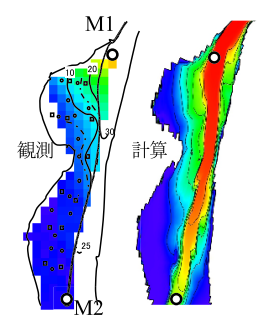

(I) 8/6 18:00

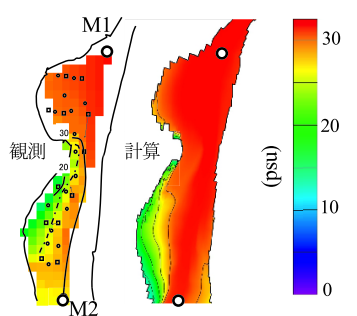

(II) $8 / 7$ 0:00
図-7 塩水侵入期間（2002年 8月 6〜 7日）における浅瀬での 塩分分布（河床上 $10 \mathrm{~cm}$ ）（I）及び（II）の時刻は図-6 に点線で示す.

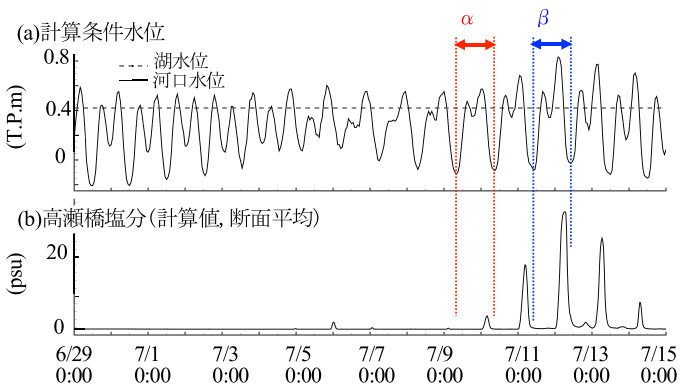

図-8 第3章の計算で使用した（a）水位条件，および（b）計 算された高瀬橋地点断面平均塩分の時系列。

初期には澪筋を塩水が速やかに遡上するのに対し（図-7 (I))，高水敷では貯留されていた河川水を上流に押し出 しながら塩水と徐々に置換されていくなど（図-7(II)), 塩分平面分布の時間変化は概ね再現されている。また， 図-6に示すように，M1 地点では上層と下層が同時に遡 上初期に速やかに高塩分に移行し長時間継続するのに対 して，M2地点では浅瀬からの低塩分河川水の表層への 排出により，遡上初期（時刻（I）から（II））には上層 塩分が低塩分となり，高水敷が塩水に満たされ河川水の 排出が完了した後に遅れて高塩分となるなど（時刻（II） 


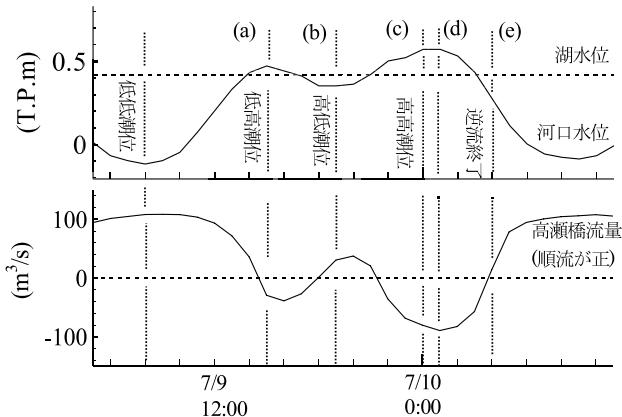

図-9 中潮（期間 $\alpha$ ) での水位と高瀬橋地点流量（計算值）.

以降), 観測された浅瀬付近での塩水挙動を計算モデル が再現していることが確認できる。なお，浅瀬への侵入 初期（図-7(I)）では，観測結果に比べ浅瀬での塩分の上 昇が早く計算される傾向にあった，原因としては，過小 な摩擦係数の採用や風応力を考慮していないなど計算モ デルに関するものの他に，河床間隙水の影響も考えられ る.つまり，実際の浅瀬の河床は高透水性の砂質土であ ることから, 塩水侵入前には淡水が間隙水として蓄えら れており，この淡水との混合・交換により塩分が希釈さ れ，実際の浅瀬では塩分の上昇が計算よりも穏やかであ った可能性がある.

\section{3. 塩水遡上規模が混合形態に及ぼす影響}

遡上規模による浅瀬での塩水挙動の差異と, その差異 が上流域での混合形態へ与える影響について検討を行う。 異なる遡上規模について考察するため, 小潮から大潮を 含む期間について新たに計算を行った。実際には2010年 6月29日から7月15日の河口実測水位を下流端境界条件 として与え, 降雨などの影響を除くため一定の湖水位 T.P. $-0.43 \mathrm{~m}$ （刘象期間の実測湖水位の平均值）を上流端 境界条件として計算を行った（図-8 (a))。その他の計算 条件は前章で述べた 2002 年の再現計算と同じとした。

高瀬橋地点における塩分の断面平均値の時間変化を図-8 (b) に示す. 中潮と大潮の期間である7月9日から 15 日 にかけて湖に達する塩水遡上が見られた。そのうち, 遡 上が小規模であった中潮（図-8の期間 $\alpha$ ）と, 大規模で あった大潮（期間 $\beta$ ）について比較を行った.

中潮（期間 $\alpha$ ）について, 図-9に水位と高瀬橋地点で の流量を，図-10には浅瀬での塩分分布の時間変化を, 図-11には澪筋に沿った河道縦断方向の塩分分布を示す. 図-10（a) と（b）に示す様に，小規模遡上の場合には，日 潮不等のうち低低潮位から低高潮位までの期間には塩水 は澪筋に沿って遡上し, 浅瀬 (高水敷) への塩水侵入と それによる河川水の置換は見られない，その後，高低潮 位から高高潮位の期間で初めて浅瀬への侵入が開始し て, 図-10（c）に示すように, 河口水位が最大となる高

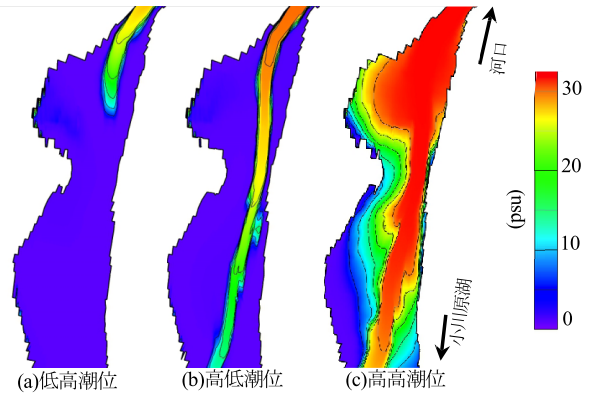

図-10 中潮（期間 $\alpha$ ）における浅瀬での塩分分布（河床上 $10 \mathrm{~cm})$. (a)〜 (c) の時刻は図-9に示す。

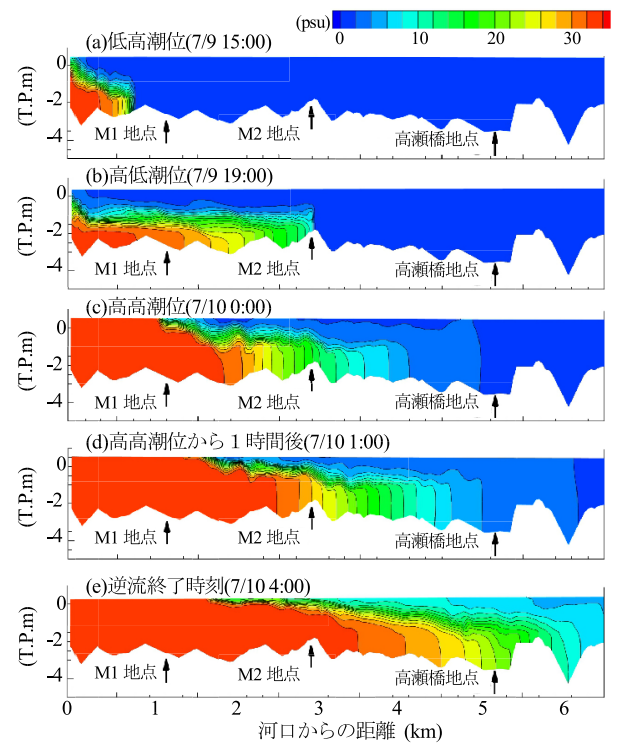

図-11 中潮（期間 $\alpha$ ）における澪筋に沿った縦断塩分分布. (a)〜 (e) の時刻は図-9に点線で示す.

高潮位でも浅瀬には河川水が残り，遡上が見られた全期 間を通じて河川水の排水が継続し続けている。 その結果, 図-11 (e) に示すように, 塩水層が最も進展する逆流終了 時でも, 浅瀬からの河川水の排出により, 浅瀬より上流 域では表層は低塩分となる緩混合状態が維持されること が確認でき, 浅瀬から上流側表層へ低塩分の河川水が継 続的に排出されることが小規模遡上の場合に緩混合状態 を生じる原因となることが分かる.

一方，遡上規模が大きかった大潮時（期間 $\beta$ ）には，日 潮不等が大きくなるため（図-12），低高潮位には既に浅瀬 への塩水侵入と河川水の置換が開始され（図-13 (a)), 順 流に転じて塩水が後退する低高潮位から高低潮位の期間で も下流側の浅瀬に塩水が留まっている(図-13(b))。 その 結果, 図-13(c) に示すように, 再度逆流となり小川原湖 に向けて塩水が大きく遡上する高低潮位から高高潮位で は, 河川水の塩水による置換と浅瀬から上流側表層への低 塩分河川水の排出は高高潮位を迎える以前に速やかに完了 


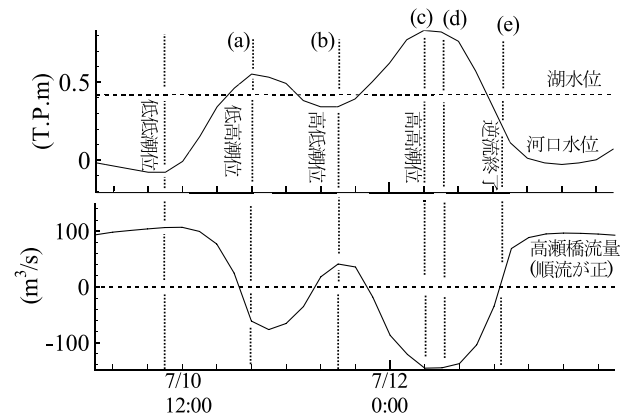

図-12 大潮（期間 $\beta$ ) での水位と高瀬橋地点流量（計算值）.

している，そのため，塩水遡上が活発となる高高潮位ごろ には，浅瀬より上流域では表層の低塩分層は維持されず， 図-14の（c）から（e）の縦断図に示す様に, 全層混合状 態と成って湖に到達していることが確認できる.

\section{4. まとめ}

高瀬川に扔ける塩水遡上の三次元数值解析から，河口 付近から中流域の浅瀬の存在が上流域での塩水混合形態 に影響を及ぼすこと，既往研究において示唆されてきた 混合形態変化の発生機構が実際に生じうることが示され た. 即ち，（1）浅瀬に貯留されていた河川水の上流側澪 筋表層への排出が湖付近の上流域での塩分鉛直分布に影 響を及ほすると，（2）規模の小さい塩水遡上では浅瀬か らの河川水の排出が長期間継続するため，塩水遡上期間 を通じて上流域で緩混合状態が維持されること，一方，

（3）大潮時など日潮不等が大きく遡上が大規模となる時 には，浅瀬での河川水の置換とその上流への排出は早期 に完了するため，表層への低塩分河川水の供給は持続せ ず，上流域で強混合状態となることなどが確認された。

本研究を行うにあたり，国土交通省東北地方整備局高 瀬川下流河川事務所には貴重なデー夕をご提供いただき ました。ここに記して謝意を表します。

\section{参 考 文 献}

石川忠晴・坂井雅之・小沢康彦（1991）：小川原湖に侵入する 塩分の計算モデルの検討, 水工学論文集, 第 35 卷, pp.191-196.

許 暁飛 - 中村恭志 - 小林 侑 - 小島 崇 - 石川忠晴 （2012）：CIP-Soroban三次元流動モデルによる利根川感潮 域塩水流動解析, 水工学論文集, 第 56卷, pp.1555-1560.

鶴田泰士 - 石川忠晴 - 西田修三 - 藤原広和 - 村井禎美 (2001)：小川原湖への海水侵入現象に関わる水理デー夕 の整備と復元，水文・水資源学会誌，第 14巻，pp.13-26.

鶴田泰士 - 石川忠晴 - 西田修三 - 成田 舞 - 藤原広和 (2002）：小川原湖に打けるヤマトシジミの繁殖環境につ いて, 土木学会論文集, No.705/II-59, pp.175-187.

土木学会編 (1999)：水理公式集, $89 \mathrm{p}$.

中村恭志・石川忠晴 (2010)： CIP-Soroban法に基づく汽水域3 次元数值流動モデルの開発, 水工学論文集, 第 54 巻, pp.1441-1446.
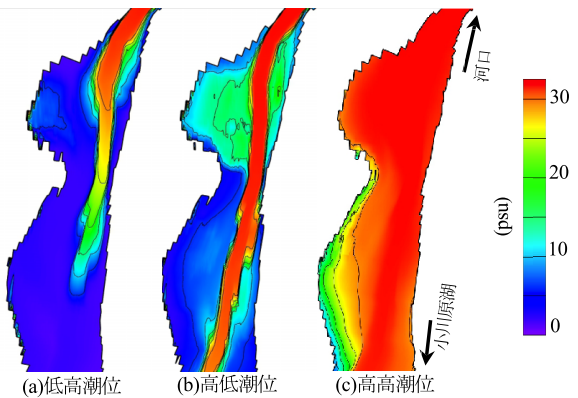

図-13 大潮（期間 $\beta$ ）に扔ける浅瀬での塩分分布（河床上 $10 \mathrm{~cm})$. (a)〜 ( c) の時刻は図-12に点線で示す.

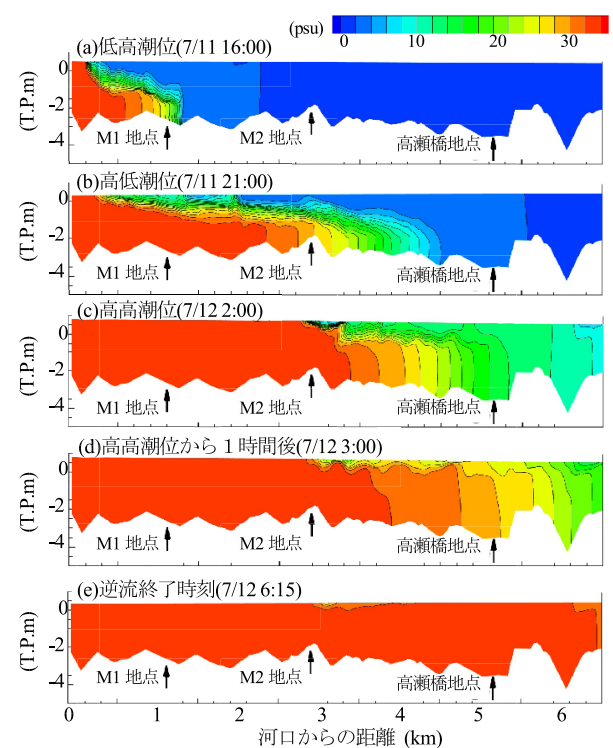

図-14 大潮（期間 $\beta$ ）における澪筋に沿った縦断塩分分布. (a)〜 (e) の時刻は図-12に点線で示す.

長尾正之・西部隆宏 - 石川忠晴・山浦勝明（1996）：小川原湖 への塩分侵入現象の確率統計的考察, 水工学論文集, 第 40 卷, pp. $583-588$.

成田 舞・石川忠晴・藤原広和・和光一紀 (2003)：高瀬川中 下流部の浅瀨が塩水遡上に及ぼす影響について，水工学 論文集，第47巻，pp.955-960.

西田修三・中辻啓二（1999）：緩混合河川に打ける流量と塩分 輸送量の算定, 水工学論文集, 第43巻, pp.869-874.

西田修三・佐野俊幸・中辻啓二（2001）：汽水湖に打ける流動 構造と物質循環過程, 海岸工学論文集, 第48巻, pp.11161120.

藤原広和・沢本正樹・神山尚人（1995）：複断面水路に扔ける 河口密度流の混合特性, 海岸工学論文集, 第 42 巻, pp.416-420.

藤原広和・沢本正樹・田中博通（1997）：複断面及び単断面水 路に㧍ける密度流の混合特性の相違について, 水工学論 文集，第 41 巻，pp.515-520.

藤原広和 - 石川忠晴 - 西田修三 - 鶴田泰士 - 沢本正樹 （2000）：高瀬川の複断面河道部に抢ける塩水遡上特性, 水工学論文集, 第44卷, pp.1005-1010.

$\mathrm{Ji}, \mathrm{Z}$. (2008): Hydrodynamics and water quality, Wiley, $47 \mathrm{p}$. 